\title{
Job security in a packaging and distribution of hydrochloric acid company
}

\section{Seguridad laboral en una empresa de envasado y distribución de ácido clorhídrico}

\author{
LÓPEZ-VIGIL, Miriam Silvia†๋, SANTOS-ALAVARADO, Héctor, GARCÍA-MEJÍA, Javier Martín, \\ GONZÁLEZ MELO, Omar and MATÍAS-LÓPEZ, Ramón
}

Tecnológico Nacional de México
Instituto Tecnológico de Tehuacán

ID $1^{\text {st }}$ Author: Miriam Silvia, López-Vigil / ORC ID: 0000-0002-7424-0109, CVU CONACYT ID: 300532

ID $1^{\text {st }}$ Coauthor: Héctor, Santos-Alvarado

ID $2^{\text {nd }}$ Coauthor: Javier Martín, García-Mejía

ID $3^{\text {rd }}$ Coauthor: Omar, González-Melo

ID $4^{\text {th }}$ Coauthor: Ramón Matías López.

DOI: $10.35429 / J L D E .2019 .4 .3 .25 .33$

Received January 29, 2019; Accepted June 18, 2019

\begin{abstract}
Hydrochloric acid is a chemical compound with broad applications in industry, chemistry, mainly used for the manufacture of agrochemicals, veterinary products, production of PVC, the process of demineralization of water, activation of oil fields, process of tanning skins, process of stamping in the textile industry, production of pharmaceuticals as well as applications in the food industry as an additive in the manufacture of gelatin and sugar. In recent years in Mexico, the chemical industry has held between the third and fourth place in the value of GDP is a $10.7 \%$ of this (INEGI, 2015). The growth of this industry every year, explains the increase in the demand for the product of the study dedicated to the purchase, storage, packaging and distribution of hydrochloric acid and muriatic. This company raises the need to distribute their areas of production, optimizing the working conditions and the need to expand to implementing a better distribution of plant that guarantees the security of the worker and increase its production capacity and competitiveness.
\end{abstract}

Job security, Hidrochloric acid, Risks

\begin{abstract}
Resumen
El ácido clorhídrico es un compuesto químico con amplias aplicaciones dentro de la industria, principalmente la química, utilizado para la fabricación de productos agroquímicos, productos veterinarios, elaboración de PVC, el proceso de desmineralización del agua, activación de yacimientos de petróleo, proceso de curtido de pieles, proceso de estampado en la industria textil, producción de productos farmacéuticos así como aplicaciones en la industria alimentaria como aditivo en la fabricación de gelatina y azúcares. En los últimos años en México la industria química ha ocupado entre el tercer y cuarto lugar en el valor del PIB es decir un $10.7 \%$ de este (INEGI, 2015). El crecimiento de esta industria año con año, explica el aumento en la demanda del producto de la empresa en estudio dedicada a la compra, almacenamiento, envasado y distribución de ácido clorhídrico y muriático. Esta empresa plantea la necesidad de distribuir sus áreas de producción, optimizar las condiciones de trabajo y la necesidad de expandirse implementando una mejor distribución de planta que garantice la seguridad del trabajador e incremente su capacidad productiva y competitividad.
\end{abstract}

Seguridad laboral, Ácido clorhídrico, Riesgos

Citation: LÓPEZ-VIGIL, Miriam Silvia, SANTOS-ALAVARADO, Héctor, GARCÍA-MEJÍA, Javier Martín, GONZÁLEZ MELO, Omar and MATÍAS-LÓPEZ, Ramón. Job security in a packaging and distribution of hydrochloric acid company. RINOE Journal-Labor and Demographic economic. 2019. 3-4: 25-33.

\footnotetext{
* Correspondence to Author (email: misilovi@ hotmail.com)

$\dagger$ Researcher contributing first author.
} 


\section{Introduction}

Hydrochloric acid is a chemical compound, formed by a solution in water of hydrogen chloride gas, it is an acid of high thermal stability with a wide variety of applications, it is considered among the inorganic compounds of greater use and importance on an industrial scale (Acids .info, 2017). It receives a variety of different common names that change depending on the geographical area, so for example it is known mainly in America as muriatic acid, while its common name in Spain is strong water, other names it also receives are: spirit of salt, salt acid, chloric acid and marine acid.

Hydrochloric acid, has as its main characteristics its high corrosive and acidic power, it is also in a liquid state as it is an aqueous solution with a slight yellowish hue. In a gaseous state it weighs more than air and has a smell that irritates the mucous membranes and eyes. It is usually treated in chemistry as a strong acid, since it dissociates completely in the aqueous solution; It is usually used as a reagent. Its $\mathrm{pH}$ is usually lower than 1 , so it is dangerous and even lethal to humans if ingested, even a small amount. It is naturally present in the gases emitted by volcanoes, which when exposed to air form dense and corrosive white vapors. In addition, gas is also formed by burning some types of plastics, and as soon as it comes into contact with water, the formation of $\mathrm{HCl}$ takes place. Chemically, hydrochloric acid is a monoprotic type acid, that is, it only releases one proton $(\mathrm{H}+)$. When in an aqueous solution, said ion binds to an $\mathrm{H}_{2} \mathrm{O}$ molecule, resulting in the production of an oxonium ion $\left(\mathrm{H}_{3} \mathrm{O}+\right)$. Along with oxonium, the formation of another ion, chloride (Cl-), is also given. That is why hydrochloric acid can be used in preparations of chloride salts. $\mathrm{HCl}$ is an acid considered strong, because when it is in water, it suffers a complete dissociation, it is a strong acid not very dangerous to work if we compare it with other strong acids such as Sulfuric acid, in addition to $\mathrm{HCl}$ solutions that have concentrations tights, are usually highly stable, being able to maintain over time, so they can be prepared and preserved for later use. All this, together with that it can be achieved as a reagent in its purest form, makes $\mathrm{HCl}$ a reagent widely used to acidify, as well as an acid titrant used in volumetric processes. It has a wide use in chemical analysis for volumetries and for the digestion of various analytical samples.
Apart from its use as a reagent, hydrochloric acid has numerous uses not only because of its strong acid characteristics but also because it is economical, stable, high in water and volatile. Among these uses is the removal of limestone residues (Calcium Carbonate, $\mathrm{CaCO}_{3}$ ) whose presence can cause fouling and sealing of pipes, in this process limestone dissolves when reacting with hydrochloric acid forming calcium chloride $\left(\mathrm{CaCl}_{2}\right)$ with release of $\mathrm{CO}_{2}$ and $\mathrm{H}_{2} \mathrm{O}$. In the branch of organic chemistry, $\mathrm{HCl}$, is used in the synthesis of some organic acids. Another important application for $\mathrm{HCl}$ is its participation to regenerate ion exchange resins. In the food industry, $\mathrm{HCl}$ is used in the production of gelatin, because it dissolves bone parts. It has wide use in the production of cleaning products, it is used in the treatment of metals, in the treatment of leather as well as in the manufacture of numerous and varied industrial products.

In spite of being highly used, it is not free of harmful effects on health, since $\mathrm{HCl}$, besides being corrosive, is quite irritating to any mucosa or tissue that is in its contact or inhalation. Causing from sore throat to suffocation depending on the exposure time. Some sensitive people cause inflammatory reactions.

When $\mathrm{HCl}$ is mixed with bleach, or other oxidizing agents, a toxic chlorine gas is produced. Always depending on the concentration of the acid used and exposure to it, it can cause from mild irritation, to serious burns, either on the skin or in eyes or other areas. Longterm exposure, even at small levels, will cause breathing problems, mucosal irritations and also teeth, which will discolor. The gastric juices that are secreted in the stomach have an $\mathrm{HCl}$ content of about $3 \%$, which gives it a role of coenzyme in the digestion of food, to digest proteins and in the hydrolysis of the polysaccharides that we can ingest through the diet. The stomach $\mathrm{HCl}$ is produced by the parietal cells of the stomach, which is protected against the action of said acid, but when some of the protection processes fail, the known stomach ulcers occur (Méndez, 2013). Free chlorine is the most commonly used disinfectant, it is classified as an oxidizing agent. When free chlorine is added to water, it quickly reacts with it to form hypochlorous acid ( $\mathrm{HOCl})$ and Hydrochloric acid $(\mathrm{HCl})$ according to reaction 1 :

$\mathrm{Cl}_{2(\mathrm{~g})}+\mathrm{H}_{2} \mathrm{O} \rightarrow \mathrm{HOCl}+\mathrm{HCl}$ 
Although chlorine disinfection is very effective (mainly against bacteria and viruses) and with cost advantages, the use of chlorine has some disadvantages such as the formation of byproducts, since chlorine reacts with dissolved organic matter present in the water at disinfect and form trihalomethanes (THM) which are carcinogenic (Mihelcic, J. and Zimmerman J., 2012). The regulations of the World Health Organization for chlorine establish a maximum allowed limit of $5 \mathrm{mg} / \mathrm{L}$ and NOM 127 SSA11994 of $0.2-1.5 \mathrm{mg} / \mathrm{L}$. Chlorine produces water flavor, its detection threshold being $0.6-1.0 \mathrm{mg}$ / L. While chemical products can be useful, it is necessary to take measures to prevent and keep under control the potential risks for workers, workplaces and the environment (ILO, 2014).

Occupational safety includes a set of measures and activities developed to minimize or eliminate the risks arising from the performance of a job. Understanding by risk according to the USEPA (United States Environmental Protection Agency, 2001) any possibility of something happening with negative consequences.

The company under study is dedicated to the purchase, storage, packaging and distribution of hydrochloric and muriatic acid, in the presentation of pet and polyethylene bottles in measures of $0.5,1$ and 4 liters as well as 70, 120, and 200-liter gallons.

Every organization is responsible for the safety and health at work (OSH) of its workers and that of other people who may be affected by their activities (Muñoz, 2019).

Nowadays the company does not have the capacity to cover the increasing demand of its products because its productive capacity is limited by the lack of facilities and the poor distribution of plant; and for not having the regulations implemented in its facilities. Consequently, the company sees the need to carry out the plant distribution design based on the current safety guidelines in order to expand by implementing a distribution that guarantees worker safety and the application of the regulations for its correct operation.

\section{Objective}

Perform the analysis of occupational safety needs in the design of plant distribution of a hydrochloric acid packaging and distribution company.

\section{Methodology}

The research method used in this project was descriptive, since the first action was to describe the current situation of the company, which starts from the general problems to individuals, where the main problem was identified and described, which starts with the poor distribution of the company's plant which does not guarantee operator safety. Another method used in this investigation is the explanatory one, since the causes of the company's problems were searched, such as that the company does not have defined work areas, the lack of work methods and the presence of occupational accidents, which have an impact in occupational hazards that are present in the daily work in the facilities. The scope of the methodological research is to propose a distribution of facilities that will allow the company to increase its production, guaranteeing worker safety, giving it a better workspace and facilities. The design of the present investigation is not experimental, therefore, the variables of the work were not objects of prior control or corrective in the development of the investigation, leaving the observed events to evidence data without manipulative intervention by the researcher. On the other hand, this study was determined as a field investigation, since the data collection process was carried out in a company in the Tehuacán Region, being a case study. Field research was carried out in characteristic phases of a methodical process and follows the form of the scientific method to solve the problem, this process is as follows (Muther, 1981):

- The clear statement of the problem or task.

- Facts that can be measured.

- New approach to the problem in light of the facts.

- Objective analysis that leads us to a decision.

- Action to get approval and installation.

- Tracking and checking.

LÓPEZ-VIGIL, Miriam Silvia, SANTOS-ALAVARADO, Héctor, GARCÍA-MEJÍA, Javier Martín, GONZÁLEZ MELO, Omar and MATÍAS-LÓPEZ, Ramón. Job security in a packaging and distribution of hydrochloric acid company. RINOE JournalLabor and Demographic economic. 2019 
In order to assess the risks and propose corrective and control actions to guarantee occupational safety.

\section{Results}

\section{Primary information}

The collection of qualitative data from primary sources was obtained directly with interviews with workers and guided observation tours in the visits to the company under study which has a total of ten employees: five operators in the production process and five in management activities , sales, purchases and multiple activities of the company. The interviews were applied to the five operators dedicated to the production process and to three members of the company's trustworthy staff: general manager, sales manager and production manager. The company is classified as microenterprise by its number of workers (DOF, 2002) and has more than 25 years in the market and currently in its product catalog is bottled hydrochloric acid in the presentations of:

- 500 milliliter bottle.

- 1 liter bottle.

- 4 liter gallon.

The process for the packaging of hydrochloric acid, in its different presentations currently consists of 7 stages as shown in Figure 1, which are performed manually, without having clear and adequate facilities for production. The parts used in the process are not manufactured, all are purchased and arrive at the company of suppliers from different cities. The sales market is mainly carried out in the Tehuacán region and the distribution of the products is carried out by the members of the company.

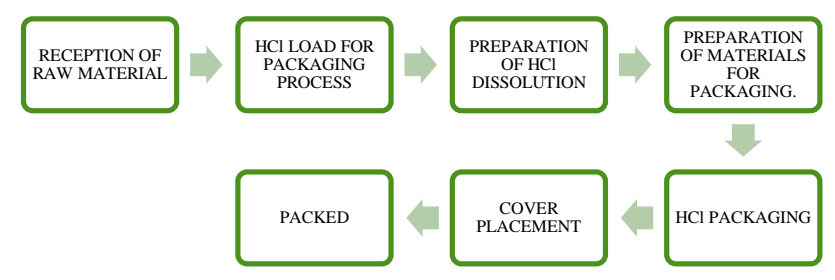

Figure 1 Diagram of the current production process
- Reception of raw material: this process begins with the admission of hydrochloric acid which is received by a worker, this makes the connection of hoses and the manual filling of storage tanks.

- Preparation of $\mathrm{HCl}$ : at this point the worker loads the hydrochloric acid to casks, then move them to the production area, for the preparation of the solution.

- Preparation of the $\mathrm{HCl}$ solution: the worker adds distilled water to the tanks, dye and mix until the desired characteristics are obtained.

- Preparation of the material to start packaging: the operator places the tools for packaging such as the hoses, keys and tools for production.

- $\mathrm{HCl}$ packaging: the operator starts the continuous filling of a batch of bottles, which are arranged on the floor of the work area, the operator performs the sitting operation and filling is done manually.

- Cap placement: the operator goes to the warehouse through the lid bag, returns to its area for the placement of bottle caps, the operation is performed manually.

- Packaging: for the packaging of hydrochloric acid, the operator goes to the warehouse through the package of boxes, the boxes are armed by the worker and then the bottles are packed. After packing and closing the boxes, the operator estiva boxes and takes them to the warehouse of finished product.

The materials involved in the different parts of the process are the following:

- Hydrochloric Acid $(\mathrm{HCl})$ in concentration from $28^{\circ}$ to $30^{\circ}$.

- Bottle of: 500 milliliters, 1 liter and 4 liters.

- Bottle cap: 500 milliliters, 1 liter and 4 liters.

- Carton box.

- Tags. 
- Yellow Pigment.

- Paste tape.

The preparation of the solution is carried out in the company's facilities, in which hydrochloric acid, distilled water and pigment are added, this solution is carried out in a two hundred liter tambo and as all operations are performed manually. The bottles used for packaging carry a label, with the brand, the name of the product and necessary information, the activity of placing the label on the different bottle presentations is carried out externally:

- External operation: Manual labeling to bottle.

Both operators and managers perform various functions in the company according to its needs, such as: receipt of raw materials, purchases of raw materials, preparation of raw materials, packaging, packaging, loading and unloading of products, sales and administration . The company does not have established processes, in this case the operator with more experience teaches new workers the steps to perform for the filling of bottles since there are no manuals of the process in the company, this brings with it that there is ignorance and doubts about the different activities and the correct way to do them, with the risk that the possible errors entail. Both managers and workers are not clear about the departments that exist in the company, since in the existing areas there are multiple activities, the current facilities of the members of the company only recognize that they have a production area and warehouse of raw material. No worker or manager has received information or training on the management of hydrochloric acid. Recommendations have been received from the supplier regarding the handling of the material, but mainly knowledge about this substance has been obtained over the years, with the daily handling of the product. The high command of the company does not have a clear concept of what a personal protection equipment is and the importance of this, there is a lack of knowledge and little culture on this issue, in addition to the fact that the company provides few elements of personal protection to its workers, the lack of regulations in the company contributes to the operator not using these elements and in the same way the nonapplication of regulations.
$90 \%$ of workers consider that they carry out activities that put them at risk, such as the reception of hydrochloric acid, the loading of acid for the packaging process and as such the exposure to this substance, in the interviews we can notice that workers have a concept, although not very deep, of what labor safety means, since for them it is that they have no accidents in carrying out their activities; for this they indicate that the occurrence of accidents is very low, they have had cases of skin irritation, spills on their clothes, splashes in the eyes or spills on the floor, however they do not consider them risky. The managers consider that the treatment of their workers is in a respectful, fair and accessible way, as they seek to provide a pleasant working environment, as well as make them participate in the success of the company for which a positive communication with them is important. They recognize that the tasks and responsibilities of the company are not clear and are unknown to some, due to the lack of organization, the lack of assignment of responsibilities and the lack of an organization chart in the company. They are aware of the danger posed by the operator's exposure to hydrochloric acid, so they seek to improve the company's infrastructure, to offer a better workspace, to have growth and to be a successful company in the region. At the moment the high command of the company, looks for governmental supports for the expansion of his company, with a proposal that guarantees so much the increase of his productive capacity as the labor security. From the analysis of the current problem, the main factors involved in the process were identified and the cause-effect diagram shown in Figure 2 was designed, such as: material, labor, movements, facilities and work tools.

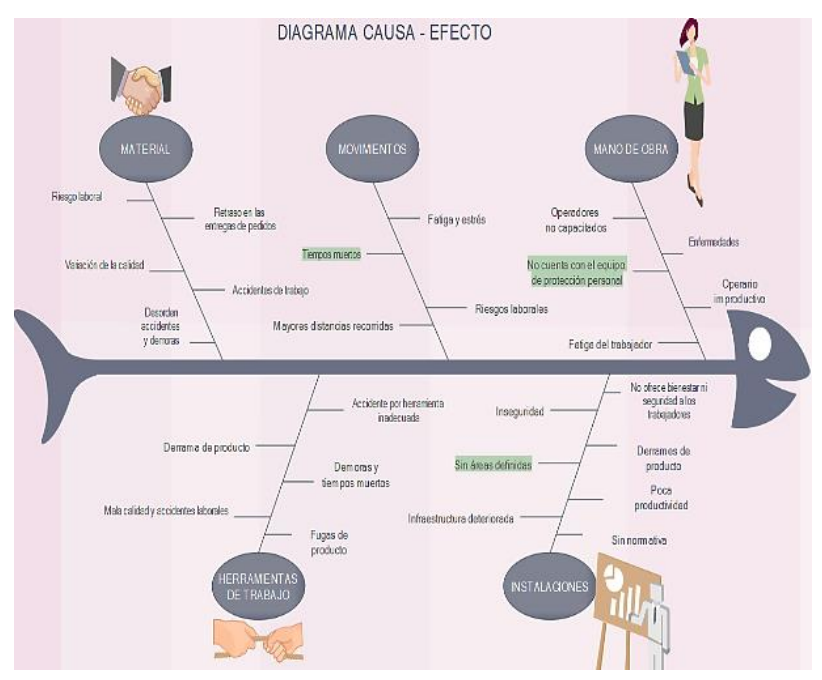

Figure 2 Cause-effect diagram of the current production process

LÓPEZ-VIGIL, Miriam Silvia, SANTOS-ALAVARADO, Héctor, GARCÍA-MEJÍA, Javier Martín, GONZÁLEZ MELO, Omar and MATÍAS-LÓPEZ, Ramón. Job security in a packaging and distribution of hydrochloric acid company. RINOE JournalLabor and Demographic economic. 2019 
Of the various problems presented in the company, a histogram was shown, which is shown in figure 3 , where it is identified that the origins of the majority lie in the damaged infrastructure that can cause an accident, the lack of defined areas that generate disorder and operations unproductive, as well as the lack of standards applied in the company that result in the lack of guarantee in the worker's safety. Given this situation and taking into account compliance with the Official Mexican Standards (NOM) (table 1) it is proposed to the company:

- Design of the hydrochloric acid warehouse.

- Design of the hydrochloric acid discharge lines.

- Design of a mechanism to capture gases in the hydrochloric acid storage area.

- Proposal for hydrochloric acid storage tanks and use tools for the production process.

- Proposal of personal protective equipment.

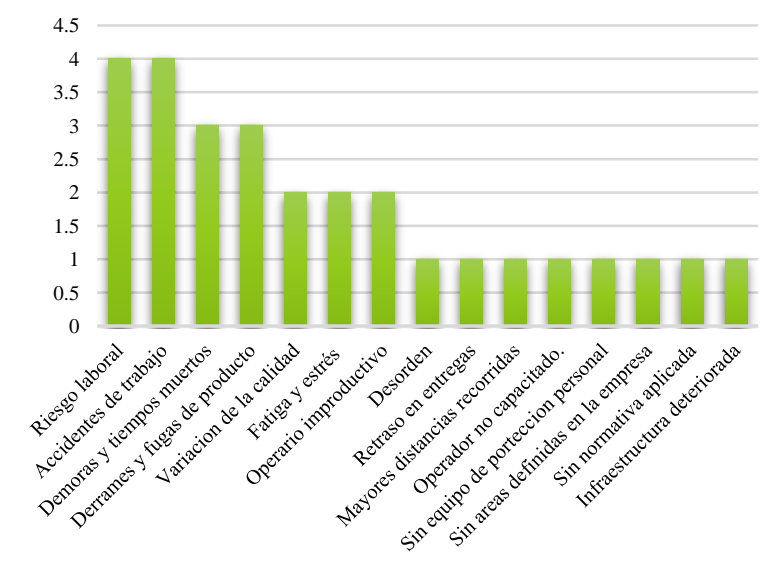

Figure 3 Results Histogram

Of the 42 existing NOMs, 12 are on occupational safety, 8 health, 9 product; 6 of organization and 7 for specific activities.

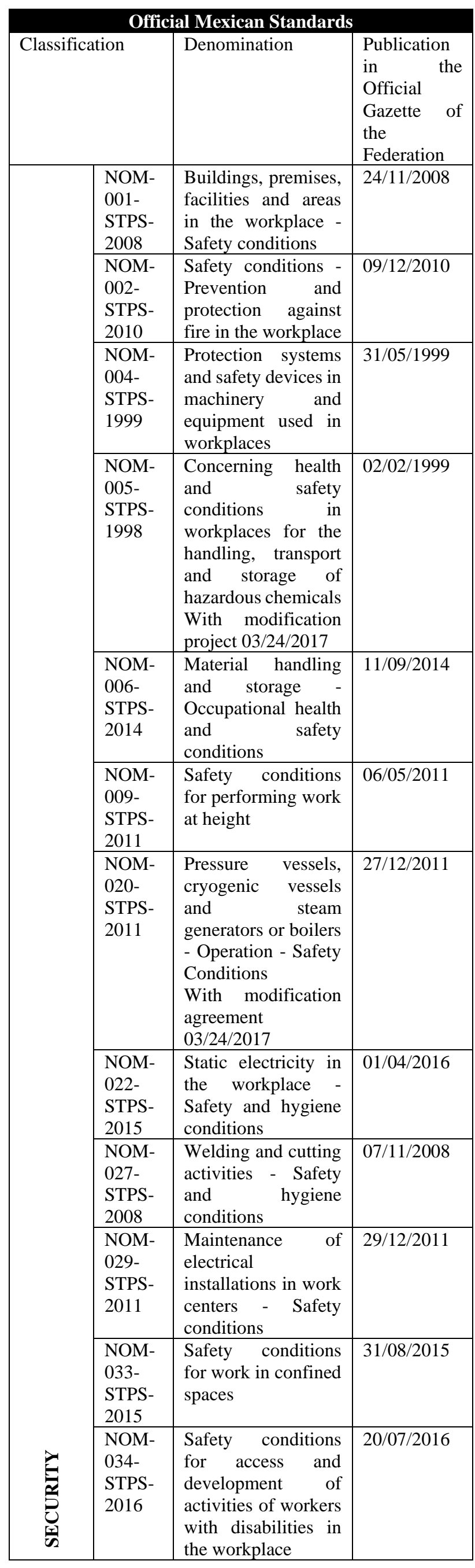

LÓPEZ-VIGIL, Miriam Silvia, SANTOS-ALAVARADO, Héctor, GARCÍA-MEJÍA, Javier Martín, GONZÁLEZ MELO, Omar and MATÍAS-LÓPEZ, Ramón. Job security in a packaging and distribution of hydrochloric acid company. RINOE JournalLabor and Demographic economic. 2019 


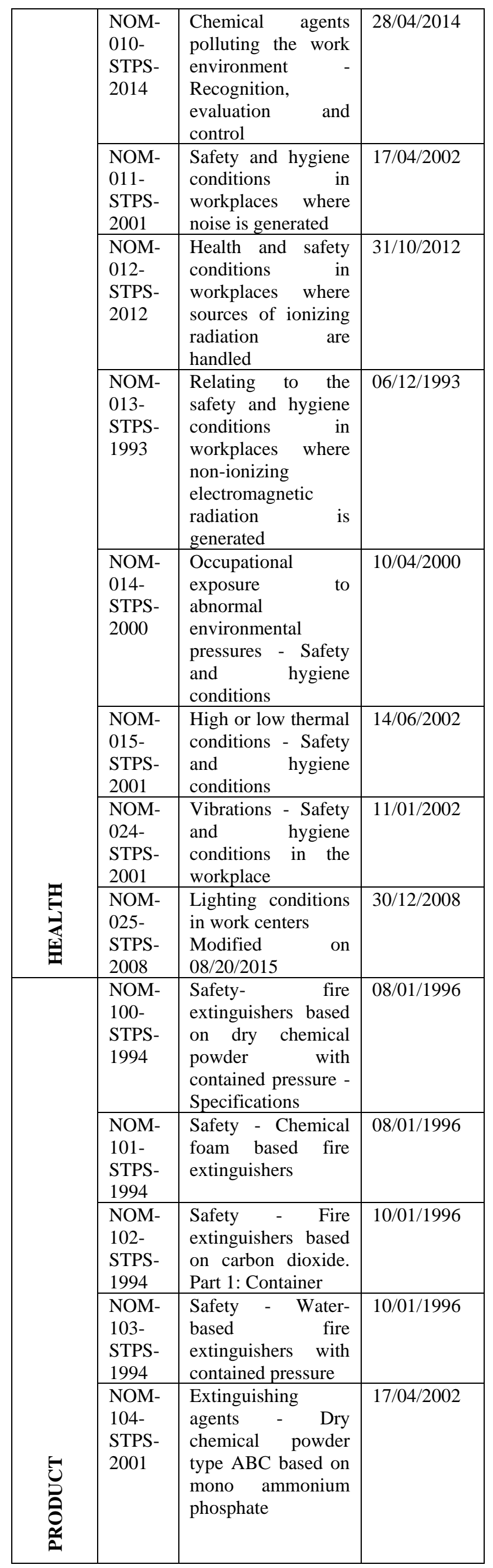

\begin{tabular}{|c|c|c|}
\hline $\begin{array}{l}\text { NOM- } \\
106- \\
\text { STPS- } \\
1994\end{array}$ & $\begin{array}{l}\text { Safety- } \\
\text { Extinguishing } \\
\text { agents - dry } \\
\text { chemical powder } \\
\text { type BC, based on } \\
\text { sodium bicarbonate }\end{array}$ & 11/01/1996 \\
\hline $\begin{array}{l}\text { NOM- } \\
113- \\
\text { STPS- } \\
2009\end{array}$ & $\begin{array}{l}\text { Safety - Personal } \\
\text { protective } \\
\text { equipment } \\
\text { Protective footwear } \\
-\quad \text { Classification, } \\
\text { specifications and } \\
\text { test methods } \\
\text { It was modified on } \\
12 / 24 / 2010\end{array}$ & $16 / 12 / 2009$ \\
\hline $\begin{array}{l}\text { NOM- } \\
115- \\
\text { STPS- } \\
2009\end{array}$ & $\begin{array}{l}\text { Safety in personal } \\
\text { protective } \\
\text { equipment, } \\
\text { protective helmets, } \\
\text { classification, } \\
\text { specifications and } \\
\text { test methods } \\
\text { It was modified on } \\
12 / 24 / 2010 \text { and } \\
6 / 7 / 2013\end{array}$ & $22 / 12 / 2009$ \\
\hline $\begin{array}{l}\text { NOM- } \\
116- \\
\text { STPS- } \\
2009\end{array}$ & $\begin{array}{l}\text { Safety - Personal } \\
\text { protective } \\
\text { equipment } \\
\text { respirators negative } \\
\text { pressure air purifiers } \\
\text { against harmful } \\
\text { particles } \\
\text { Specifications and } \\
\text { test methods } \\
\text { It was modified on } \\
12 / 24 / 2010\end{array}$ & $22 / 12 / 2009$ \\
\hline
\end{tabular}

Table 1 NOM summary of work safety, health and product

From the proposed departments an analysis of the relationship between them is shown in Figure 4, the criteria to rate the intensity of relationship are based on the need and importance of the proximity between departments.

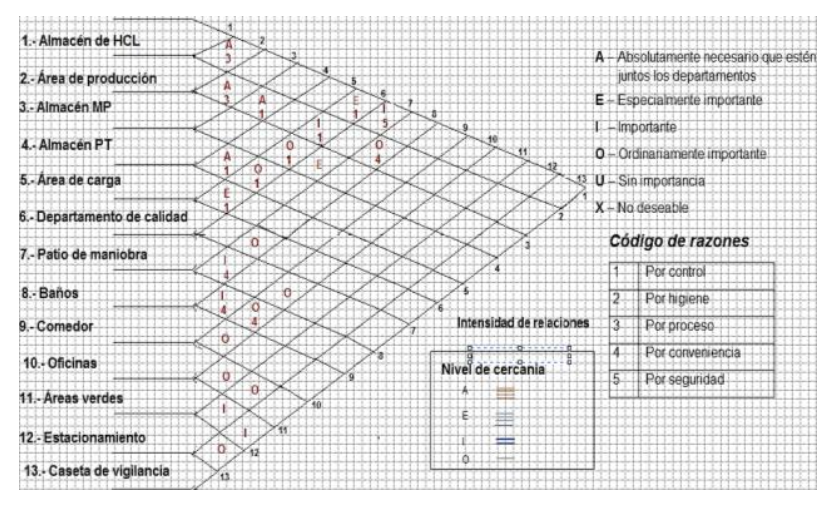

Figure 4 Department Relationship Analysis

The proposed plant distribution that complies with the regulations and consequently guarantees occupational safety is shown in Figure 5.

LÓPEZ-VIGIL, Miriam Silvia, SANTOS-ALAVARADO, Héctor, GARCÍA-MEJÍA, Javier Martín, GONZÁLEZ MELO, Omar and MATÍAS-LÓPEZ, Ramón. Job security in a packaging and distribution of hydrochloric acid company. RINOE JournalLabor and Demographic economic. 2019 

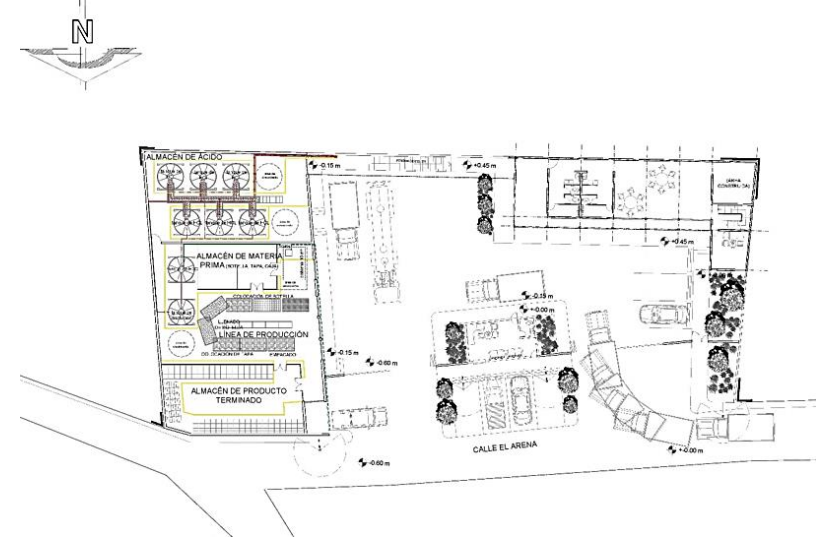

Figure 5 Distribution plant

A good distribution should be complemented with adequate training on occupational safety and the use of personal protective equipment (epp) as they are:

- Mask for inorganic vapors.

- Neoprene gloves or long cane rubber.

- Wide vision and safety glasses.

- Personal protective clothing for corrosive chemicals.

\section{Conclusions}

Workers who are in direct contact with hazardous substances have the right to work in safe and healthy working conditions, they must also be duly informed, trained and protected. Given the risks involved in working with hydrochloric acid, it is necessary to emphasize the importance of occupational safety and the needs of any company, including SMEs, to implement these measures. Work spaces must be safe and protect workers, since the work is essential for life, development and personal satisfaction, but in some cases the performance of work activities represents a risk to the health of the worker and even for the environment in general. The obtaining of primary data allowed to obtain a diagnosis of the current state of the company and to know how to work, to know more about the process and aspects of worker safety. The proposal of the new warehouse generates important changes throughout the process, in addition to reducing the contact of the worker with hydrochloric acid, the collection of gases decreases the leakage of particles of the substance in the environment
The proposed process allows the elimination of $50 \%$ of unnecessary activities, in addition to improving the flow of materials and operators, and reducing the risk of accidents. For the design of the plant, aspects of flow were considered mainly, in order to facilitate movements and improve logistics within the company, observing the applicable regulations. The application of the results will increase worker safety, improve organizational aspects in the company and implicitly improve production aspects.

\section{References}

Ácidos.info (s/a). (2017). Ácido Clorhídrico, propiedades y aplicaciones de esta solución. Disponible en: https://acidos.info/clorhidrico/\#Aplicacionesdel-acido-clorhidrico

DOF. (30 de diciembre de 2002). Diario Oficial de la Federación. Ley para el Desarrollo de la Competitividad de la Micro, Pequeña y Mediana Empresa. Disponible en: http://www.diputados.gob.mx/LeyesBiblio/inde x.htm

Hernández, M. (2019). Propuesta de gestión en seguridad en la manipulación de productos químicos para el tratamiento de aguas en piscinas de la Empresa Costamar. Tesis para obtener el título de Ingeniero en Prevención de Riesgos Laborales y Ambientales. Universidad Técnica Federico Santa María Sede de Concepción - Rey Balduino de Bélgica, disponible en https://repositorio.usm.cl/bitstream/handle/1167 3/46842/3560901543781UTFSM.pdf?sequence $=1 \&$ isAllowed $=\mathrm{y}$

INEGI (2015). Instituto Nacional de Estadistica y Geografia. PIB y cuentas nacionales. Disponible en: inegi.org.mx/temas/inai

Méndez, A. (2013). Ácido Clorhídrico, La guía de Química. Disponible en: https://quimica.laguia2000.com/gases/acidoclorhidrico

Mihelcic, J. y Zimmerman J., (2012). Tratamiento de Aguas. Ingeniería Ambiental, Fundamentos, Sustentabilidad, Diseño. Editorial Alfaomega, México. 
Muther, R.(1981). Distribucion de planta. Mc Graw Hill, España. ISBN-10: 8425504619

OIT. (2014). Organización Internacional del Trabajo. La seguridad y salud en el uso de productos químicos en el trabajo. Disponible en: https://www.ilo.org/safework/events/meetings/

WCMS_235598/lang--es/index.htm

USEPA. (2001). United States Environmental Protection Agency. An overview of Risk Assessment and RCRA. EPA530-F00-032: Washington D.C. 